University of Nebraska - Lincoln

DigitalCommons@University of Nebraska - Lincoln

Publications from USDA-ARS / UNL Faculty

U.S. Department of Agriculture: Agricultural

Research Service, Lincoln, Nebraska

2001

\title{
History, current status, and collaborative researchprojects for Bemisia tabaci
}

M. R. V. Oliveira

Embrapa Recursos Genéticos e Biotecnologia

T. J. Henneberry

USDA

P. Anderson

Centro Internacional de Agricultura Tropical

Follow this and additional works at: https://digitalcommons.unl.edu/usdaarsfacpub

Part of the Agricultural Science Commons

Oliveira, M. R. V.; Henneberry, T. J.; and Anderson, P., "History, current status, and collaborative researchprojects for Bemisia tabaci" (2001). Publications from USDA-ARS / UNL Faculty. 352.

https://digitalcommons.unl.edu/usdaarsfacpub/352

This Article is brought to you for free and open access by the U.S. Department of Agriculture: Agricultural Research Service, Lincoln, Nebraska at DigitalCommons@University of Nebraska - Lincoln. It has been accepted for inclusion in Publications from USDA-ARS / UNL Faculty by an authorized administrator of DigitalCommons@University of Nebraska - Lincoln. 


\title{
Review article
}

\section{History, current status, and collaborative research projects for Bemisia tabaci ${ }^{\text {光 }}$}

\author{
M.R.V. Oliveira ${ }^{\mathrm{a}}$, T.J. Henneberry ${ }^{\mathrm{b}, *}$, P. Anderson ${ }^{\mathrm{c}}$

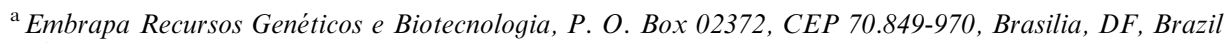 \\ ${ }^{\mathrm{b}}$ USDA, Western Cotton Research Laboratory, 4135 E. Broadway Rd, Phoenix, AZ 85040, USA \\ ${ }^{\mathrm{c}}$ Centro Internacional de Agricultura Tropical, A. A., 6713, Cali, Colombia
}

Received 28 November 2000; received in revised form 8 August 2001; accepted 9 August 2001

\begin{abstract}
Bemisia tabaci was described over 100 years ago and has since become one of the most important pests worldwide in subtropical and tropical agriculture as well as in greenhouse production systems. It adapts easily to new host plants and geographical regions and has now been reported from all global continents except Antarctica. In the last decade, international transport of plant material and people have contributed to geographical spread. B. tabaci has been recorded from more than 600 plant species and there may be many additional hosts not yet formally documented. Biotypes have been identified in different areas of the world suggesting that $B$. tabaci may be a species-complex undergoing evolutionary change. These biotypes may exhibit differences in viruses transmitted and transmission efficiency, rates of development, endosymbionts, host utilization, and physiological host damage. Excessive $B$. tabaci induced losses worldwide occur in field, vegetable and ornamental crop production. Losses occur from plant diseases caused by $B$. tabaci transmitted viruses, direct feeding damage, plant physiological disorders, and honeydew contamination and associated fungal growth. The number of $B$. tabaci-transmitted plant viruses has increased, and total yield losses of important food and industrial crops has occurred. Effective control at present is dependent on insecticides. However, this has been achieved with more selective chemistries, use of action thresholds, and resistance management. Host plant resistance and various cultural methods are also components of developing integrated management systems. National and international collaborative projects have made significant progress towards improved characterization of the whitefly problem, increased research, development of management methods, transfer of technology to the agricultural communities, and information exchange. These projects, as well as intensive education, research and extension activities form the basis for biologically and ecologically based approaches to management. Published by Elsevier Science Ltd.
\end{abstract}

Keywords: Bemisia argentifolii; Bemisia tabaci; Pest; Geminivirus; Economics; IPM

\section{Contents}

1. History . . . . . . . . . . . . . . . . . . . . . . . . . 710

2. Host range and biotypes . . . . . . . . . . . . . . . . . . . . . 710

3. Economic impact. . . . . . . . . . . . . . . . . . . . . . . . . 711

3.1. B. tabaci-transmitted viruses . . . . . . . . . . . . . . . . . . . . . 713

3.2. B. tabaci-induced plant physiological disorders and other aspects of plant damage . . . . 714

\footnotetext{
Recent evidence suggests that B. tabaci represents a species complex with numerous biotypes and two described cryptic species. The binomial B. tabaci here is used in the broadest sense to include all member of the species complex unless a more specific designation is indicated.

This article reports the results of research only. Mention of a proprietary product does not constitute an endorsement or a recommendation for its use by EMBRAPA or USDA.

*Corresponding author. Tel.: + 1-602-437-0121; fax: +1-602-437-1274.

E-mail addresses: vilarin@cenargen.embrapa.br (M.R.V. Oliveira), thenneberry@wcrl.ars.usda.gov (T.J. Henneberry), p.anderson@cgiar.org (P. Anderson).
} 
4. Control and IPM perspectives . . . . . . . . . . . . . . . . . . . . . . . . . . 714

5. International and national collaborative research projects . . . . . . . . . . . . 715

5.1. CGIAR Whitefly IPM project. . . . . . . . . . . . . . . . . . . . 715

5.2. Five-year national research action plan for development of management and control methodology for the sweetpotato whitefly . . . . . . . . . . . . 717

Acknowledgements . . . . . . . . . . . . . . . . . . . . . . 718

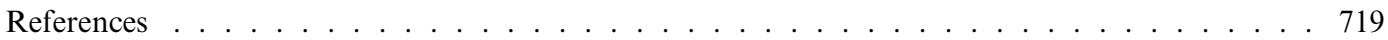

\section{History}

Bemisia tabaci (Hemiptera: Aleyrodidae) was described in 1889 as a tobacco pest in Greece and named Aleyrodes tabaci, the tobacco whitefly (Gennadius, 1889). The first B. tabaci in the New World were collected in 1897 in the United States on sweetpotato. It was originally described as Aleyrodes inconspicua Quaintance and given the common name of sweetpotato whitefly (Quaintance, 1900). In 1928, it was found in Brazil on Euphorbia hirtella and described as $B$. costalimai Bondar (Mound and Halsey, 1978). In 1933, the species was collected in Taiwan and described as B. hibisci (Mound and Halsey, 1978). Further extension of its geographical range from subtropical and tropical agriculture systems has occurred to include temperate climate areas; the species is now globally distributed and found on all continents except Antarctica (Martin, 1999; Martin et al., 2000).

The evolutionary affiliations of the Bemisia taxa within the family Aleyrodidae suggest that B. tabaci may have originated in tropical Africa and was introduced quite recently into the Neotropics and southern North America (Campbell et al., 1996). Some evidence also suggests that $B$. tabaci may be native to India or Pakistan, where the greatest diversity of the species' parasitoids have been found, a criteria that has been considered a good indication of a genus epicenter (Brown et al., 1995). A detailed review of the nomenclature issues surrounding the Bemisia species complex is provided elsewhere in this volume by Perring (2001).

Since the 1980s, B. tabaci population outbreaks and $B$. tabaci-transmitted viruses have become a limiting factor in the production of food and fiber crops in many parts of the world (Brown, 1994). For example, populations of $B$. tabaci in the Imperial Valley of California increased 300-fold from the mid-1970s to the mid-1980s, and 1600-fold from the mid-1970s to the mid-1990s (Wisler et al., 1998). Numerous reviews are available on the B. tabaci-transmitted plant viruses (Costa, 1969, 1976; Bird and Marmorosch, 1978; Goodman, 1981; Bock, 1982; Harrison, 1985; Brown and Bird, 1992; Brown, 1994; Duffus, 1996; Polston and Anderson, 1997; Wisler et al., 1998; Brown, 2001a, b; Morales and Anderson, 2001). The increasing economic impact of whitefly populations and whitefly transmitted viruses are discussed below.
B. tabaci also is a major pest of greenhouse crops, particularly ornamentals, although major crops under greenhouse production such as tomato, pepper, beans, eggplant, and cucumber are also attacked (Cock, 1986). B. tabaci was first reported causing damage to greenhouse ornamentals in the United States by Price et al. (1986). Rapid spread occurred across the United States and currently $B$. tabaci is the most difficult pest to manage on many greenhouse crops. The presence of whiteflies on ornamental crops, phytotoxicity resulting from the need for frequent insecticide use, and accumulation of honeydew or sooty mold on leaves of infested plants reduces product aesthetic quality. The geographic range of B. tabaci now extends to Japan, Canada and the Netherlands, where greenhouse crops are affected. A complete report of the B. tabaci problems in greenhouse production systems is beyond the scope of this presentation. Readers are referred to the reviews of Oetting and Buntin (1996) and Heinz (1996) for further information.

\section{Host range and biotypes}

B. tabaci has been recorded from more than 600 different plant species (Mound and Halsey, 1978; Greathead, 1986; Secker et al., 1998) and its polyphagous nature has been documented worldwide (Bird, 1957; Costa and Russell, 1975; Bird and Marmorosch, 1978; Butler et al., 1986; Costa and Brown, 1990, 1991; Costa et al., 1991; Burban et al., 1992). A large number of cultivated and noncultivated annual and perennial plant species are recognized as acceptable feeding and/or reproductive hosts (Butler and Henneberry, 1986; Bedford et al., 1992, 1994a; Brown et al., 1992, 1995). Of the plant species listed by Mound and Halsey (1978), 50\% belong to five families: Fabaceae, Asteraceae, Malvaceae, Solanaceae and Euphorbiaceae. Among the plant families, the number of host plants per family ranges from 99 species in the Fabaceae (Basu, 1995) to one species each in the Begnoniaceae, Lythraceae and Zygophyllaceae (Mound and Halsey, 1978). The complex host plant association of $B$. tabaci is epitomized in Puerto Rico where the polyphagous Sida biotype and the monophagous Jatropha biotype occur in the same geographical area but occupy separate ecological niches (Brown et al., 1995). The current lists of host plants 
(Mound and Halsey, 1978; Greathead, 1986) are conservative. For example in Brazil, B. tabaci has been found infesting a number of new crop and weed hosts (Lima et al., 2000; Oliveira et al., 2000b). New weed hosts include: Cleome espinosa (Cleomaceae), Senna obtusifolia (Fabaceae), Herisanthia hemoralis (Malvaceae), Richardia grandiflora, Borreria verticilliata (Rubiaceae), Waltheria indica, W. rotundifolia (Sterculicaceae), and Stachytarpheta sanguinea (Verbenaceae) (Oliveira et al., 2000b); Solanum ambrosiacum (Solanaceae), Pavonia cancellata, Herissantia crispa (Malvaceae), Diodia teres (Rubiaceae), and Phyllanthus tenellus (Euphorbiaceae) (S.D. Vasconcelos, personal communication). Newly reported hosts in the USA include: Hyperium perfolatum (Hypericaceae), Valeriana officinalis (Valerianaceae), Tanacetum parthenium, Echinacea pallida, E. purpurea (Asteraceae) (Simmons et al., 2000).

The wide range of variations in pupal characteristics (Mohanty and Basu, 1986) may be related to adaptation to new hosts and acclimation to different geographical regions. Host-correlated variation in the morphology of pupal integument of B. tabaci was demonstrated by Mound (1963) on tobacco and cassava and by Azab et al. (1969), on cabbage, cotton, Euphorbia pulcherrima and Lantana camara (Ananthakrishnan, 1976; Basu, 1995). Mohanty and Basu (1986) and Basu (1995) demonstrated the combined effect of host plant and seasonal factors on pupal morphology.

According to Basu (1995), severe field population outbreaks of B. tabaci in various parts of the world during the last decade and differences in the range of host plants in different localities suggest a broad range of genetic differences within and between populations. Some recent findings indicate that adaptation (through selection) of local populations of B. tabaci to an initially poor host plant can occur within a few generations (Basu, 1995).

The polyphagous nature of $B$. tabaci may contribute to documented biotype variability in virus transmission (Brown and Bird, 1992; Bedford et al., 1994a; Duffus, 1996; Markham et al., 1996); different rates of development (Wang and Tsai, 1996), and morphological variation in endosymbionts (Costa et al., 1995). Also, differences occur in host utilization (Brown and Bird, 1992; Burban et al., 1992; Bedford et al., 1994a), ability to induce physiological changes in some hosts (Costa and Brown, 1991; Cohen et al., 1992; Bedford et al., 1994a), and the occurrence of esterase and DNA profile differences (Liu et al., 1992; Gawel and Bartlett, 1993; Wool et al., 1993, 1994; Coats et al., 1994; Legg et al., 1994; Brown et al., 1995; De Barro and Driver, 1997; Guirao et al., 1997; Gunning et al., 1997).

In the past decade, extensive and intensive surveys of $B$. tabaci have been conducted to detect the spread of the $B$ biotype, and identify other biotypes within the $B$. tabaci species complex (Brown, 1993, 1994; Basu, 1995;
Brown et al., 1995; Markham et al., 1996; Chermiti et al., 1997; Guirao et al., 1997; De Barro et al., 1998; Quintero et al., 1998; Abd-Rabou, 1999; Berdiales et al., 1999; Sauvion et al., 1999; Robledo and Sagahón, 1999; De Barro and Hart, 2000; De Barro et al., 2000; Demichelis et al., 2000; Lee et al., 2000; Lima et al., 2000; Oliveira et al., 2000a; Banks et al., 2001). The diverse array of tools utilized for molecular analysis and interpretation of results has made it difficult to compare results and draw conclusions. However, knowledge is advancing rapidly and an improved understanding of $B$. tabaci systematics and epidemiologically useful distribution patterns are likely in the near future.

\section{Economic impact}

Reliable estimates of the economic impact of the B. tabaci species complex on worldwide agriculture have been difficult to obtain because of the extensive areas affected, the numbers of crops and ornamentals involved, and different monetary systems. Over the last three decades, B. tabaci has caused excessive annual crop losses. The impact of direct feeding and honeydew excreta that favors sooty mold production are factors that affect crop yield in both quantitative and qualitative terms. Increased control costs and reduced product marketability and profitability are also important factors (Ellsworth, 1999).

B. tabaci was first reported to be a serious pest of cotton in the late 1920s and early 1930s in northern India (now part of Pakistan) (Misra and Lamba, 1929; Husain and Trehan, 1933). Subsequently, severe infestations on cotton were recorded in the Sudan and Iran (1950s), El Salvador (1961), Mexico (1962), Brazil (1968), Turkey (1974), Israel (1976), Thailand (1978), Arizona and California, USA (1981), and Ethiopia (1984) (Basu, 1995).

Historically, heavy infestations in cotton fields often resulted in significant dispersal to other field crops and vegetables following termination of the cotton crop. Insecticide use in many cases resulted in the development of resistance and a general failure of control efforts. In the Sudan, Dittrich et al. (1990) attributed part of the problem to the ability of insecticide-resistant B. tabaci individuals to increase their oviposition rates when under insecticidal stress (hormoligosis). In contrast, Eveleens (1983) considered suppression of aphelenid parasitoids with broad-spectrum insecticides as a major cause of the B. tabaci outbreaks. Castle (1999) reappraised the Sudan- $B$. tabaci situation and offered a more complex explanation for the outbreaks. His counter argument to the pesticide-induced $B$. tabaci problem involved the influence of agricultural intensification of cotton acreage, increased fertilizer use and other production technology, later planting dates, and 
managerial overuse of insecticides. It is likely that all of these factors have affected $B$. tabaci population outbreaks.

In the USA, B. tabaci had been a long time resident in various agricultural regions throughout the southern and western states but rarely was an economic pest until 1981 when serious outbreaks occurred in California and Arizona. In 1986 in Florida, poinsettias were heavily infested with whiteflies, and silverleaf symptoms were reported in squash (Price et al., 1986; Maynard and Cantliffe, 1989). California's Imperial Valley felt the full destructive potential of the insect in 1991 (Toscano et al., 1998). The losses caused in Arizona, California, Texas, and Florida, in 1991 and 1992 were estimated at about 200 and 500 million US\$, respectively; and in Imperial Valley, California, between 1991-1995, over 100 million US\$ annually (Birdsall, personal communication). Between 1994-1998, Arizona, California and Texas cotton growers spent 153.9 million US\$ (Ellsworth et al., 1999) to control B. tabaci and prevent cotton lint stickiness. In a socio-economic impact study in California, Gonzalez et al. (1992) concluded that for every $\$ 1$ million dollars of primary-induced crop loss, there was an estimated $\$ 1.2$ million in loss of personal income as well as the elimination of 42 jobs.

The years 1991 and 1992 were critical to Mexico, when $B$. tabaci caused losses exceeding 33 million US\$ by damaging fall melon and watermelon, sesame and cotton crops in the Mexicali Valley. Also in Mexicali Valley, cotton production was reduced from 39,415 ha in 1991 to only 653 ha in 1992 (R.L. López, pers. comm.; Medina Esparza and Leon Paul, 1994). The area planted with cotton between 1995 and 1996 in Sonora, Mexico was reduced by $65 \%$ as a result of $B$. tabaci infestations (Silva Sanchez, 1997).

Soybean production in Sonora, Mexico has also been greatly impacted by $B$. tabaci infestations. Areas planted ranged from 89,000 to 124,000 ha from 1992 to 1994 (E. Gutierrez-Martinez-Carrillo, personal communication) and profitability was marginal. Increasing $B$. tabaci infestations began to occur in 1991. Chemical control costs were about $\$ 120 /$ ha and not considered particularly effective. Yields declined and profitability was reduced further (American Soybean Association, 2000). Subsequently, soybean production decreased to 25,000 , 75, 20 and 420 ha, respectively, in 1995, 1996, 1997 and 1998 (E. Gutierrez-Martinez-Carrillo, personal communication). Production since 1998 has been about 500 ha, annually. B. tabaci has not been a limiting production factor on the reduced acreages grown in the last several years. Other factors such as increasing production costs, available water, and declining economies have also contributed to the current low acreages (American Soybean Association, 2000).

In Central America and the Caribbean, extensive losses on tomato, okra, cotton, tobacco and melon have occurred in Cuba, Barbados, Costa Rica, Dominican Republic, El Salvador, Haiti, Honduras, Guatemala, Jamaica, Monserrat, Nicaragua and Santa Lucia (Hilje, 1996; Vazquez, 1999). In Guatemala, costs of whitefly control increased from $30 \%$ to $50 \%$ on melon, tomato and pepper. In 1998 and 1999, melon losses exceeding $40 \%$ as a result of sooty mold and geminiviruses have been reported (Dávila, 1999).

Since 1995, Brazil has been seriously affected by $B$. tabaci. Accumulated losses have exceeded 5 billion US\$. The main crops attacked are beans, tomatoes, cotton, melons, watermelons, okra, and cabbage, but numerous other crops are also infested. B. tabaci has spread from the Southeast to almost all areas of the country (Lima et al., 2000). Other South American countries such as Argentina (Viscarret et al., 2000), Colombia (Quintero et al., 1998), Paraguay (Oliveira and Lima, unpub.), and Bolivia (Morales and Anderson, 2001) have reported increasing problems with $B$. tabaci.

Most countries surrounding the Mediterranean Basin encountered severe $B$. tabaci infestations beginning in 1974. In Italy and southern France, severe damage occurred on poinsettias and tomatoes. B. tabaci was recorded from Azerbaijan and Georgia in the former Soviet Union, and has been observed on citrus growing in glasshouses along the southern coast of the Crimea and the Black Sea Coast of the Caucasus (Dantsing and Shenderovska, 1988; Traboulsi, 1994).

In the Near East, B. tabaci has been reported as a major pest in Algeria, Bahrain, Cyprus, Egypt, the Islamic Republic of Iran, Iraq, Jordan, Kuwait, Lebanon, Libya, Malta, Morocco, Pakistan, Saudi Arabia, Somalia, the Sudan, Tunisia, Turkey, the United Arab Emirates and Yemen. It attacks vegetables and ornamentals outdoors and under protected cultivation (Traboulsi, 1994). It also occurred on citrus and cotton in Pakistan and Israel and on olives and pears in Morocco (Traboulsi, 1994). Watermelon crops in Yemen have been decimated since 1989 (Bedford et al., 1994b).

In China, severe local outbreaks of B. tabaci were recorded in 1953 in Taiwan and in 1972 in Yunnan, and at present, B. tabaci has spread from the south to northern parts of the country (Rumei, 1996). This author also reported that previous surveys (1953-1992) identified six provinces where B. tabaci occurred. In 1995 , this area had expanded to 12 provinces.

In 1994, B. tabaci was reported in cotton in Australia. It was first described in the country in 1959 but it had not been an economic problem (Gunning et al., 1995; Carver and Reid, 1996; Fransmann et al., 1998). In the mid-1990s, in the Pacific Region, B. tabaci was found on 18 islands including: Cook Island, Guam, New Caledonia, American Samoa, Fiji, Marshall Islands, Niue, Federated States of Micronesia, Kiribati, Papua New Guinea, and Solomon Islands (De Barro et al., 1998). 
The magnitude of B. tabaci infestations and the nature and extent of injury vary with plant species, season and localities. Some plant species that are severely infested in one area, may be relatively free of infestation in other areas. For example, B. tabaci is a serious threat to cotton in Sudan but an insignificant problem on cotton in Egypt. Cassava is affected in Africa but not in South America (Costa and Russell, 1975). In Brazil, passion fruit has only recently been attacked by the biotype B, but in Minas Gerais, losses vary from $60 \%$ to $100 \%$ according to farmers of the region (M.R.V.O., personal observation).

\subsection{B. tabaci-transmitted viruses}

B. tabaci transmits plant viruses in seven distinct virus groups including: geminiviruses, closteroviruses, carlaviruses, potyviruses, nepoviruses, luteoviruses and a DNA-containing rod-shaped virus (Duffus, 1987, 1996). The most economically significant of these are the geminiviruses (Family Geminiviridae: Genus Begomovirus) and the closteroviruses (Family Closteroviridae: Genus Crinivirus). Cassava, beans, cowpea, soybean, cotton, tobacco, tomatoes, peppers, okra, squash, melon, watermelon, lettuce and papaya have been affected by one or more whitefly transmitted viral diseases. However, geminiviruses infecting tomatoes, beans, and cassava have been cited as the most widespread and important.

Tomatoes, in almost all countries where they are grown commercially, are infected with geminiviruses. In the Middle East, Tomato yellow leaf curl virus (TYLCV) outbreaks were sporadic in the 1960s (Cohen and Harpaz, 1964), but have become a serious economic problem since the early 1970 s, when total crop failures occurred (Czosnek and Laterrot, 1997). By the end of the 1970s, all tomato-producing regions in the Middle East were affected by the virus (Cohen and Harpaz, 1964; Yassin and Nour, 1965; Makkouk et al., 1979; Mazyad et al., 1979; Ioannou, 1985; Abak et al., 1991; Czosnek and Laterrot, 1997). In southern Europe, extensive tomato losses have been caused by TYLCV (Giustina et al., 1989; Benuzzi et al., 1990; Traboulsi, 1994). The virus is now distributed in Asia, Africa, Europe, the Caribbean, Mexico and North America.

A review by Polston and Anderson (1997) on the tomato-infecting geminiviruses in Latin America indicated that the number of new geminiviruses infecting tomatoes increased from three in the 1970s to 17 in the 1990s. Some of these geminiviruses also infect peppers and other horticultural crops of economic importance (Morales and Anderson, 2001).

According to Polston and Anderson (1997), no formal crop loss assessments have been made for the tomato diseases caused by geminiviruses, but empirical data suggest the potential for extensive reductions in crop production. In the Dominican Republic, crop damage reported from 1988 to 1995 ranged from 5 to $95 \%$ with economic losses of 10 million US\$ in 1988, and 50 million US\$ between 1989 and 1995. In Florida, USA, disease caused by Tomato mottle virus was found in all tomato production areas reducing the value of the 19901991 production by $20 \%$ or 140 million US\$. Puerto Rico suffered an estimated 40 million US\$ loss, and in Honduras, tomato production in the Comayagua Valley losses were estimated at 4.6 million US\$ in 1992. In Brazil, economic loss estimates have not been made, but in the last 4 years, more than 11,000 jobs have been lost in the tomato industry because of whitefly transmitted geminiviruses and other factors (M.R.V.O., personal observation).

Numbers of whitefly transmitted geminiviruses, numbers of crops affected, yield losses, and agricultural areas devastated have been exceptionally high in Latin America (Morales and Anderson, 2001). Common bean is grown on more than 9 million ha with Brazil producing over $50 \%$ of the total crop harvested (Morales and Anderson, 2001). Bean golden mosaic virus (BGMV) and Bean golden yellow mosaic virus (BGYMV) are considered the most limiting pathogens to common bean production in the Americas. Over one million hectares traditionally planted to beans have been abandoned because of bean golden mosaic disease (Morales and Anderson, 2001).

The most serious whitefly virus-vectored problem in Africa is cassava mosaic disease (CMD) caused by a complex of cassava mosaic geminiviruses (Hong et al., 1993; Harrison et al., 1997; Zhou et al., 1997). Cassava is the most important food crop grown on the African continent, and yield losses due to CDM are excessive. Yield losses range from insignificant to $95 \%$ depending upon the cultivars used, environmental conditions, and geminiviruses involved (Legg, 1999).

Although Cotton leaf curl virus (CLCV) has been known for many years in Pakistan (Mahmood, 1999), rapid spread of the disease started in 1988 (24 ha) and increased to about 121,458 ha in 1992 reducing cotton production by $30-40 \%$ in 1993 and 1994. Estimates of losses from 1994 to 1999 were about 7.4 million cotton bales valued at 4.98 billion US\$ (Mansoor et al., 1999). In India, CLCV was first detected from Sri Gangenagar in 1993 and Punjab in 1994 (Singh et al., 1999). At present, it is widespread over the entire northern cottonproducing zone of India. In Punjab (India), cotton production in 1998 decreased $75 \%$ compared to 1990 (Singh et al., 1999). Cotton leaf curl is suggested as a major factor in the decline.

Mung bean yellow mosaic virus (MYMV) is a major constraint to the cultivation of grain legumes in India, particularly mung bean (Phaseolus aureus) and black gram (P. mungo). According to Varma et al. (1992), in epidemic years, losses due to MYMV have exceeded 300 
million US\$ in three major crops: black gram, mung bean and soybean (Basu, 1995). Okra yellow vein mosaic virus in India, Sri Lanka and Bangladesh occurs in cultivated vegetable crops, with losses reported to exceed $80 \%$ if the plants are infected within 4-5 weeks after germination (Basu, 1995).

The whitefly transmitted closteroviruses (Family Closteroviridae: Genus Crinivirus) have recently been recognised as causing extensive losses in North America, the Mediterranean Basin and the Middle East (Wisler et al., 1998). The criniviruses are transmitted by $B$. tabaci and three other whitefly species. The B. tabacitransmitted Lettuce infectious yellows virus (LIYV) caused losses estimated at 20 million US\$ in lettuce, sugar beets and melons during the 1981 growing season (Duffus et al., 1996; Wisler et al., 1998). However, in the late 1980s and early 1990s with increasing populations of B. tabaci biotype B, the occurrence of LIYV began to decline. At present LIYV infections of lettuce and melons in Southern California and Arizona are rare (Duffus, personal communication). This has resulted from the fact that the A biotype transmits LIYV 100 fold more efficiently than the B biotype (Duffus et al., 1996). Other B. tabaci-transmitted criniviruses include: Cucurbit yellow stunting disorder virus (CYSDV), Lettuce chlorosis virus (LCV), Tomato chlorosis virus (ToCV), Sweetpotato chlorotic stunt virus (SPCSV), and a group of related closterovirus isolates infecting sweetpotato (Schaefers and Terry, 1976; Winter et al., 1992; Duffus et al., 1996; Hoyer et al., 1996; Vetten et al., 1996; Wisler et al., 1996, 1997; Livierateos et al., 1999).

\subsection{B. tabaci-induced plant physiological disorders and other aspects of plant damage}

Since 1987, increases in field populations of B. tabaci in Florida, Arizona, California, Puerto Rico, Texas, and Hawaii have been associated with plant disorders of unknown etiology (Maynard and Cantliffe, 1989; Bharathan et al., 1990; Segarra-Carmona et al., 1990; Yokomi et al., 1990; Costa and Brown, 1991; Brown et al., 1992; Cohen et al., 1992; Costa et al., 1993). Squash silverleaf (SSL) (Yokomi et al., 1990; Demichelis et al., 2000), uneven ripening of tomato (Maynard and Cantliffe, 1989), pumpkin white stem (Costa and Brown, 1991), white streaking in cole crops (Brown et al., 1992), and reduced growth, yellowing and stem blanching in lettuce and kai choy (Costa et al., 1993; Bedford et al., 1994b) have been attributed to biotype B. In Brazil, high-level infestations in okra plantings resulted in inedible woody fruit and blanching of Solanum gilo fruit (M.R.V. Oliveira, pers comm.).

B. tabaci nymphs and adults feed in phloem and obtain sap containing various sugars (Hendrix et al., 1992). Their excretions, called honeydew, may contain these and other metabolized sugars. Honeydew accu- mulates on the upper surfaces of plant parts where it serves as a substrate for sooty molds. Quality may be reduced or the product rendered unmarketable. Honeydew contamination of cotton lint makes the cotton sticky and also is a substrate for sooty molds that discolor the lint. Sticky cotton adheres to machinery in textile mills and interferes with processing. Sticky cotton reduces harvesting and ginning efficiency (Johnson et al., 1982; Hector and Hodkinson, 1989). Sticky cotton may also contain leaf trash and dirt causing health problems for textile mill workers (Ayars et al., 1986). Sticky cotton is a serious problem in many cotton production areas in the world (Strolz, 1992). Losses of $10 \%$ of the lint value may occur (Hector and Hodkinson, 1989). On vegetables, melons, and ornamentals, honeydew and sooty mold reduce quality and marketability (Riley and Palumbo, 1995).

\section{Control and IPM perspectives}

The serious nature of the B. tabaci problem worldwide has resulted in accelerated research to provide acceptable management methods (Lacey et al., 1996). Sustainable, ecologically based management systems are a goal for the future. Environmentally acceptable relief, for the present, has occurred by the integration of a number of techniques. The most effective management has been accomplished by using a combination of coordinated control strategies in agricultural community programs (see Ellsworth and Martinez-Carrillo, 2001). Detailed reviews of whitefly and whitefly transmitted virus host plant resistance, as cornerstones for sustainable IPM programs, are provided elsewhere in this volume by Bellotti and Arias (2001) and Morales (2001).

The common denominator to most B. tabaci control programs is the use of insecticides alone or in mixtures (Castle et al., 1996; Dennehy et al., 1996; Ellsworth et al. 1996b; Prabhaker et al., 1998, Palumbo et al., 2001). Insecticide resistance has been anticipated and ameliorated by the use of action thresholds and insecticide resistance management (IRM) programs (Castle et al., 1996; Dennehy et al., 1996; Ellsworth et al., 1996b; Prabhaker et al., 1996, 1998; Naranjo et al., 1998). Extensive efforts are underway to extend management systems to incorporate cultural, biological, and nonchemical methods into insecticide-based control systems as exemplified by the collection of papers in this volume. High levels of indigenous natural enemy activity have been identified in cotton, vegetable, and peanut ecosystems, suggesting that natural enemy augmentation and conservation approaches may be important avenues for exploitation in management in the future (Gerling et al., 2001; Naranjo, 2001). Row covers and other insect exclusion, and reflective type materials for repelling 
B. tabaci have been adopted and are partially effective in some cropping systems (Hilje et al., 2001). Water management has been implemented in cotton, because higher B. tabaci populations occur in water-stressed cotton (Flint et al., 1996).

Use of reliable sampling methods and action thresholds has reduced insecticide use, cost of production, and development of insecticide resistance while maintaining crop yields (Tonhasca et al., 1994a, b; Naranjo and Flint, 1994, 1995; Naranjo et al., 1995, 1996; Palumbo et al. 1994, 1995). New chemistry, such as the insect growth regulators, provide additional options in IRM programs and may delay or reduce resistance to conventional chemistries (Ellsworth et al., 1996b, 1997; Palumbo et al., 2001). Imidacloprid (Admire ${ }^{\mathbb{R}}$, a chloronicotinyl systemic insecticide, Mannheim, Germany) has been extremely effective for control of B. tabaci in vegetable production (Elbert et al., 1990; Mullins, 1993; Palumbo et al., 2001). Alternating chemistries and restricting numbers of applications per crop growing season across commodities are additional IRM tactics (Palumbo et al., 2001).

Crops grown and their temporal and spatial relationships have been recognized as important considerations in B. tabaci population dynamics (Watson et al., 1992). The extensive numbers of host-plants provide nutritional and reproductive hosts continually. Inter- and intra-host movement occurs during crop growing seasons (Byrne and Blackmer, 1996). Growers have developed an awareness of the importance of crop sequencing, wind direction, dispersal, and the proximity of host crops when establishing new plantings (Watson et al., 1992; Ellsworth, 1998). Equally important has been strict adherence to early harvests of all host crops and destruction and plowdown of crop residues.

The goal of integrating resistant crop varieties, chemical control, insecticide resistance management, crop residue and weed destruction, crop sequencing and host-free periods, and other cultural controls and management options is considered a high priority for sustainable management. In most problem areas, organizing these methods into coordinated community-action programs with extension and education activities has been very effective (e.g., Ellsworth et al., 1996a).

\section{International and national collaborative research projects}

Several national and international cooperative Bemisia projects have been implemented worldwide to facilitate communication, research, technology transfer, and rapid response to problem solving (Table 1). Additional information on these efforts is available on the listed websites. The list is not all inclusive, and the authors are aware of numerous local groups with commodity-orientation that meet informally to exchange information and experiences, and discuss current control efforts.

The international, regional and national networks for B. tabaci and B. tabaci-transmitted plant viruses and other whitefly species essentially function as information exchanges. The active international and national collaborative research projects have improved operational efficiency, by optimizing financial, physical and human resources. Open lines of communication and discussion identified priority research areas and focused efforts that increased returns for each invested research dollar compared to numerous small projects utilizing diverse approaches. Although there are many excellent examples, the authors focus on two projects with which they are most familiar.

\subsection{CGIAR Whitefly IPM project}

The Consultative Group for International Agricultural Research (CGIAR) consists of 16 International Agricultural Research Centers (IARCs) located around the world (Fig. 1). Historically, each center has worked in a relatively independent and autonomous fashion. During the 1990s, the CGIAR Secretariat recognized that significant benefits could be derived by pooling human capital, infrastructure and economic resources to jointly tackle research problems that numerous centers were working on independently. New Inter-Center initiatives included the creation of the Systemwide Program on Integrated Pest Management (SP-IPM). B. tabaci research has been on-going at several of the IARCs since the 1970s. One of the first Inter-Center projects approved within the SP-IPM was the Sustainable Integrated Management of Whiteflies as Pests and Vectors of Plant Viruses in the Tropics (the CGIAR Whitefly IPM Project).

The Whitefly IPM Project began in 1997 and evolved into a partnership among: five International Agricultural Research Centers (Fig. 1); 10 advanced research institutions in Australia, Denmark, Germany, New Zealand, the United Kingdom, and the United States; and national agricultural research systems (NARS) in 30 countries of Latin America, the Caribbean, Africa and Asia. The donor partners supporting the project included the Danish International Development Agency (DANIDA), the Australian Center for International Agricultural Research (ACIAR), the United States Agency for International Development (USAID), New Zealand's Ministry of Trade and Foreign Affairs (MFAT), the US Department of Agriculture-Agricultural Research Service (USDA-ARS), and the United Kingdom's Department for International Development (DFID). 
Table 1

Selected national and international Bemisia tabaci research and information exchange projects

Project Year created Accomplishments

International Bemisia newsletter

Sticky cotton action team, cotton incorporated (CI), Raleigh, NC

Latin America and Carribean whitefly and geminivirus network

Integrated management of whitefly in Northwestern Mexico

Five-year national research and action plan for development of management and control methodology for the sweetpotato whitefly. Revised as five-year silverleaf whitefly research, action and technology transfer plan, in 1997

The safe and effective use of pesticides project Enterprise (EMBRAPA) Project (1998-2000)

Brazilian virology project to characterize geminiviruses tomatoes
Information exchange, meeting announcements, electronic conference, Whitefly-L. Coordinators: D. Gerling, dangr@ccsg.tam.ac.il, W. Jones, wjones@weslaco.ars.usda.gov Provided communication between the cotton industry and researchers on sticky cotton research. CI and state support committees provided $\$ 1.9$ million for research. Coordinated multi-federal, -state, -university, and -industry agencies efforts that resulted in efficient whitefly management and reduced sticky cotton problems. Financed research also contributed to implementation of insect growth regulator use patterns and resistance management. Also, stimulated improved sticky cotton lint sampling methods, demonstration of the relationships of whiteflies and aphids to sticky cotton, improved sticky cotton measurement instrumentation and enzyme approaches to eliminate honeydew sugars from contaminated lint. Coordinators: R.L. Nichols, bnichols@cottoninc.com,W. Lalor, blalor@cottoninc.com Quarterly newsletter, Mosca Blanca al Dia, www.catie.ac.cr/ cooperaction/boletin.htm promotes research, diagnostic activities, and IPM technology transfer in 21 countries including Spain. Annual meeting. Network host: Tropical Agricultural Research and Higher Education Center (CATIE) Costa Rica. Coordinator: L. Hilje, lhilje@catie.ac.cr

Identified soybeans as the key host and eliminated it in the cropping system to break the reproductive host continuity. Published eight scientific summaries of 262 articles. Covered four states, Baja California Norte, Baja California Sur, Sonora and Sinola. Participating agencies are the National Research Institute of Forestry, Agriculture and Animal Husbandry (INIFAP), Regional Centers for Agricultural Research and Mexicali Experiment Station. Coordinators: J.L. Martinez Carrillo, jlmc@cirno.inifap. Conacyt.mx, J. Jose Pacheco,pacheco@cirno.inifap.conacyt.mx

1992-1996 National and international cooperative programs that led to action 1997-2001 thresholds, effective chemical control, new chemistry and resistance management principles and agricultural community management systems. Extensive basic biology, physiology, ecology for long-term suppression systems (see text). Annual meetings. Nine annual publications with over 1000 abstracts of research progress. A bibliography of more than 4800 entries: http://www.wcrl.ars.usda.gov. Coordinators: T.J. Henneberry, thenneberry@wcril.ars.usda.gov, N. Toscano,ntoscano@ucracl.ucr.edu, W. Jones, T. Perring perring@ucracl.ucr.edu, R. Faust,rmf@ars.usda.gov USAID-funded project carried out under the umbrella of the Middle East Peace Process. Annual meetings of IPM and public health experts in Egypt, Jordan, Israel and Palestine for information exchange. Pest monitoring, training of farm workers, blood testing, reports on safety progress. Information www.mercph.org. Coordinating Center: National Institute of Health (NIH), Bethesda, MD. Coordinator: K. Abdo, abdok@niehs.nih.gov Consultative Group for International Agricultural Research (CGIAR) project, under the umbrella of the Systemwide Program for Integrated Pest Management (see text). Coordinating Center: International Center for Tropical Agriculture, Cali, Colombia. Coordinator: P. Anderson, p.anderson@cgiar.org

Gathered and disseminated whitefly information. Working group meetings. Established website: www.jic.bbsrc.ac.uk/hosting/eu/ewsn Network host: John Innes Center, United Kingdom. Coordinator: Ian Bedford, ian.bedford@bbsrc.ac.uk

1998 National Whitefly Commission by EMBRAPA (3-year project). Identified priorities, coordinated efforts of the ministry, federal, state, agricultural agencies and growers. Identified infested areas, identified effective insecticides, transferred technology from other countries. Coordinator: MRV Oliveira, vilarin@cenargen.embrapa.br

$1998 \quad$ Characterized eight new tomato-infecting geminiviruses in Brazil. Developed standardized virus survey protocols, shared results, initiated varietal resistance efforts. Coordinators: F. Murilo Zerbini, zerbini@mail.ufv.br, S.G. Ribeiro, simone@ cenargen.embrapa.br 


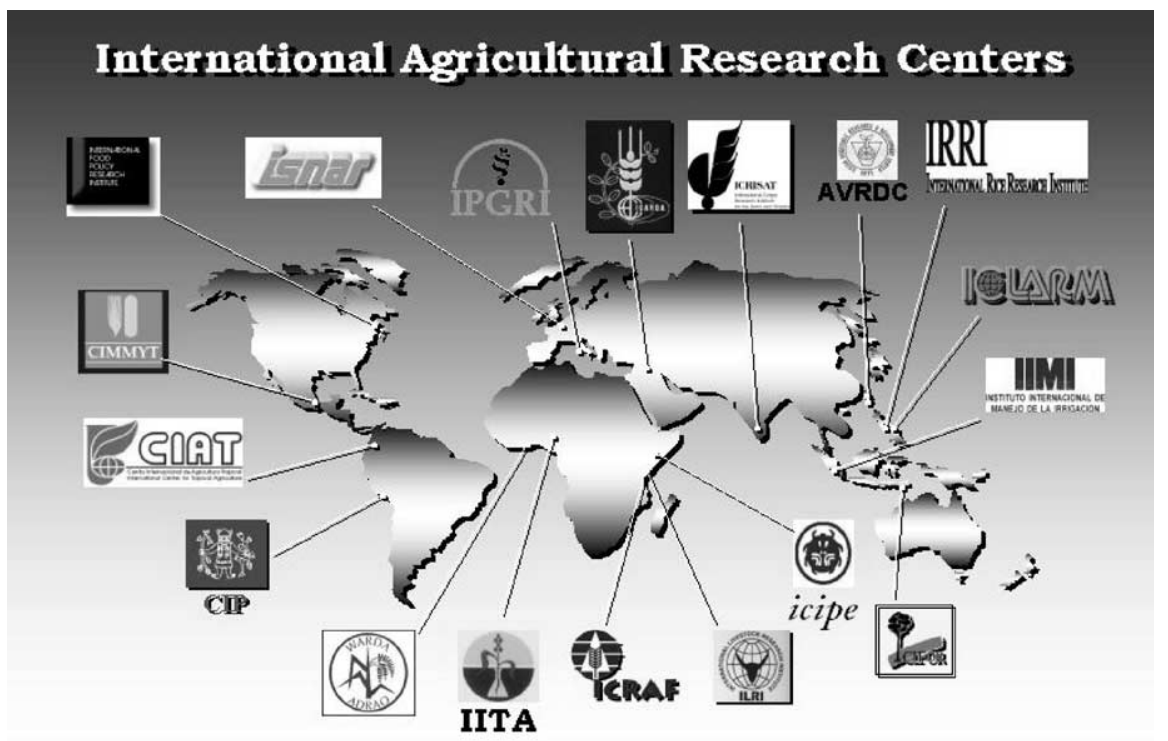

Fig. 1. Locations of International Agricultural Research Centres (IARC) of the Consultative Group for International Agricultural Research (CGIAR).

The Project was structured into six sub-projects: (1) Trialeurodes vaporariorum as a direct pest in the tropical highlands of Latin America; (2) B. tabaci as a virus vector in mixed cropping systems of the Caribbean, Mexico and Central America; (3) B. tabaci as a virus vector in mixed cropping systems of Eastern and Southern Africa; (4) B. tabaci as a virus vector in mixed cropping systems of S.E. Asia; (5) B. tabaci as a virus vector in cassava and sweetpotato in Sub-Saharan Africa, and (6) Whiteflies as direct pests on cassava in South America.

A work plan was initiated to: (1) establish an international network for research on whiteflies and whitefly transmitted viruses in the tropics; (2) characterize whitefly problems to prioritize critical target areas; (3) improve understanding of whitefly and disease dynamics in critical target areas; (4) define management strategies and develop IPM components; (5) strengthen NARS research capacity, policy formation and IPM implementation; and (6) determine Project impact.

The objective of Phase 1 (1997-2000) of the Whitefly IPM Project was to review, generate and analyze baseline data relevant to the diagnosis and characterization of whitefly and whitefly transmitted virus problems in the tropics, in order to propose a sound research agenda for improved understanding of pest and disease dynamics, IPM development and IPM implementation. B. tabaci-related reviews have been published by several of the Project coordinators (Polston and Anderson, 1997; Legg, 1999; Morales and Anderson, 2001). Baseline data were generated through extensive survey work in each of the participating tropical countries including collection and identification of biological specimens (whitefly species, whitefly biotypes, geminiviruses, and $B$. tabaci natural enemies), and collection and analysis of socio-economic data and B. tabaci control practices based on producer interviews. Preliminary results have been presented in international, regional and national meetings (Bob et al., 1997; Legg and Raya, 1998; Quintero et al., 1998; Aritua et al., 1999; Cardona, 1999; Legg et al., 1999; Morales, 2000). Reports on complete and integrated results from Phase 1 work are in preparation.

One outstanding example of management success in the Whitefly IPM Project was impact on the severe CMD epidemic in Eastern Africa. With standardized survey protocols, national teams in Uganda, Kenya and Tanzania mobilized and, within several months, had defined the front of the CMD epidemic. Based on this knowledge, funding from the USAID Office for Foreign Disaster Assistance was obtained to increase and deploy elite lines of mosaic-resistant cassava, which had been developed by the International Institute of Tropical Agriculture (IITA). The value of these crisis mitigation efforts, for the period of 1998-2000, was estimated at 14 million US\$ (USAID, 2000, internal memo), almost five times the total budget for the entire CGIAR global whitefly project during that same 3-year period.

\subsection{Five-year national research action plan for development of management and control methodology for the sweetpotato whitefly}

In the United States, unacceptable losses that occurred in the 1991 growing season highlighted 
the need for an organized, coordinated research and action effort to provide solutions to the problem and prevent the extreme losses in cotton, vegetable, ornamental and nursery production in the field and greenhouses. An ad hoc working group representing the US Department of Agriculture's Agricultural Research Service (ARS) and Animal and Plant Health Inspection Service (APHIS), State Experiment Stations and various commodity groups initiated planning for a 5-year sweetpotato whitefly research and action plan in 1991 that would serve as a guide for a national program. The sweetpotato whitefly nomenclatural confusion addressed in detail by Perring (2001) resulted in adoption of the silverleaf whitefly name in lieu of sweetpotato whitefly Strain B when the new species, $B$. argentifolii was described by Bellows et al. (1994).

The priority research areas were: (I) Basic biology, ecology, population dynamics and dispersal, (II) Fundamental research including systematics, morphology, genetics, biochemistry, physiology and behavior, (III) Chemical control, biorational insecticides and application technology, (IV) Biological control, and (V) Crop management systems and host plant resistance, and (VI) Integrated techniques, approaches and philosophies.

Annual abstracts of research progress averaged over 140 per meeting. During the first 5 -year plan, over 70 examples of Technology Transfer to growers and the scientific community were documented (Faust, 1992; Henneberry et al., 1993, 1994, 1995, 1996).

A second 5-year Plan, The Silverleaf Whitefly (Bemisia argentifolii Bellows and Perring) Research Action and Technology Transfer Plan functioned from 1997 to 2001 (Henneberry et al., 1997, 1998, 1999, 2000). The priority research areas were: (I) Biology, ecology, and population dynamics; (II) Viruses, epidemiology and virus-vector interactions; (III) Chemical control, biopesticides, resistance management, and application methods, (IV) Natural enemy ecology and biological control; (V) Host plant resistance, physiological disorders, and host-plant interactions; and (VI) Integrated and area-wide pest management approaches, and crop management systems.

For the US Five-year Plans, there also are many instances of cooperative efforts that expedited research to develop B. tabaci management tools. For example, a team of USDA-ARS and University of Arizona scientists shared resources and expertise to develop (Naranjo and Flint, 1994, 1995, Naranjo et al., 1996), validate (Ellsworth et al., 1996a; Naranjo et al., 1997), and implement (Ellsworth et al., 1996a,b) sampling methods that led to the identification and testing of action thresholds (Ellsworth et al., 1997, Naranjo et al., 1998). These teams subsequently developed rotational systems for different insecticides, evaluated new chemistries (including insect growth regulators), initiated resistance monitoring, and promoted early cotton harvests, better water management and natural enemy conservation (see Ellsworth and Martinez-Carrillo, 2001; Naranjo, 2001; Palumbo et al., 2001). Together, this system helped to reduce insecticide applications in cotton in Arizona from 6.6 in 1995 to $\cong 1.1$ in 1998 with a monetary savings of about $\$ 275.00 /$ ha (Ellsworth and Jones, 2001). The development and implementation of resistance monitoring systems (Castle et al., 1996; Dennehy et al., 1996; Prabhaker et al., 1996) have resulted in extending the efficacy of available insecticides by delaying or avoiding resistance development (Prabhaker et al., 1996).

Coordinated, multi-partner projects have a number of advantages: (1) adoption of standardized data collection protocols that are appropriate for comparison over diverse areas; (2) periodic reviews to exchange information and reprioritize research areas; (3) increased efficiency by sharing knowledge, resources and expertise; (4) multiple commodity input; and (5) increased returns per invested research dollar as opposed to multiple efforts in an uncoordinated manner.

The B. tabaci species complex has proven to be a highly diverse economic pest group that exploits diversified crop systems and weed hosts by using their high reproductive rates and short developmental times to produce explosive populations during crop production cycles. Extensive research efforts to clarify the nomenclatural issues, including biotype designations, are advancing rapidly and should soon provide answers useful to the scientific community on the interpretation of evolutionary relationships, distribution, and ecological and biological aspects of the group. The economic, environmental and social impact of the B. tabaci species complex worldwide has stimulated much new and useful research resulting in information on biology, ecology, physiology, and virus-vector interactions. Application of this information has produced efficient $B$. tabaci management systems with improved cost-benefit ratios. An important contributing factor to these successes has been participation of all aspects of agricultural communities, growers, industry and bankers, sharing and implementing information provided by researchers, extension, and educational systems to develop large-scale multidisciplinary approaches to pest management.

\section{Acknowledgements}

The authors thank Drs. Kamal Abdo, Reuben Ausher, Ian Bedford, Luko Hilje, F. Murilo Zerbini and Jose Martinez Carrillo for information supplied. The junior authors acknowledge support from the USDA-ARS-CIAT Scientific Collaborative Agreement (58-6617-9-F097). 


\section{References}

Abak, K., Yilmaz, M.A., Kesici, S., 1991. Problems caused by TYLCV in Turkey and means to fight the disease. In: Laterrot, H., Trousse, C. (Eds.), Proceedings of the EEC Seminar: Resistance of the Tomato to TYLCV. Avingnon, France, pp. 28-30.

Abd-Rabou, S., 1999. New records on whiteflies in Egypt. Egypt. J. Agric. Res. 77, 1143-1146.

Ananthakrishnan, T.N., 1976. Host correlated variation in Trialeurodes rara Singh and Bemisia tabaci (Gennadius) (Aleyrodidae: Homoptera: Insecta). Curr. Sci. 45, 223-225.

American Soybean Association, 2000. Latin America market reports. Mexico Intelligence Report: May 2000, http://www.ag.uiuc.edu/ $\sim$ asala/english/market/MEMay00. htm.

Aritua, V., Legg, J.P., Smit, N.E.J.M., Gibson, R.W., 1999. Effect of local inoculum on the spread of sweet potato virus disease: limited infection of susceptible cultivars following widespread cultivation of a resistant sweetpotato cultivar. Plant Pathol. 48, 655-661.

Ayars, G.H., Altman, L.C., O'Niel, C.E., Butcher, B.T., Chi, E.Y., 1986. Cotton dust-mediated lung epithelial injury. J. Clin. Invest. 78, 1579-1588.

Azab, A.K., Megahed, M.M., El-Mirsawi, H.D., 1969. Studies on Bemisia tabaci (Gennadius.) (Hemiptera-Homoptera Aleyrodidae). Bull. Soc. Entomol. Egypt 53, 339-352.

Banks, G.K., Colvin, J., Chowda, R.V., Maruthi, M.N., Muniyappa, V., Venkatesh, H.M., Kiran Kumar, M., Padma, A.S., Beitia, F.J., Seal, S.E., 2001. First report of the Bemisia tabaci B biotype in india and an associated tomato leaf curl virus disease epidemic. Plant Dis. 85, 231.

Basu, A.N., 1995. Bemisia tabaci (Gennadius): Crop Pest and Principal Whitefly Vector of Plant Viruses. Westview Press, New Delhi, 183pp.

Bedford, I.D., Briddon, R.W., Markham, P.G., Brown, J.K., Rosell, R.C., 1992. Bemisia tabaci-biotype characterisation and the threat of this whitefly species to agriculture. In: Brighton Crop Protection Conference-Pests and Diseases. British Crop Protection Council, Farnham, UK, pp. 1235-1240.

Bedford, I., Briddon, R.W., Brown, J.K., Rosell, R.C., Markham, P.G., 1994a. Geminivirus transmission and biological characterisation of Bemisia tabaci (Gennadius) biotypes from different geographic regions. Ann. Appl. Biol. 125, 311-325.

Bedford, I.D., Briddon, R.W., Jones, P., Alkaff, N., Markham, P.G., 1994b. Differentiation of three whitefly transmitted geminiviruses from the Republic of Yemen. Eur. J. Plant Pathol. 100, 243-257.

Bellotti, A.C., Arias, B., 2001. Host plant resistance to whiteflies with emphais on cassava as a case study. Crop Prot. 20, 813-823.

Bellows, T.S., Perring, T.M., Gill, R.J., Hendrick, D.H., 1994. Description of a new species of Bemisia (Homoptera: Aleyrodidae). Ann. Entomol. Soc. Am. 87, 195-206.

Benuzzi, M., Nicoli, G., Manzaroli, G., Bravaccini, F., 1990. Lotta biológica e integrata su poinsettia. Inf. Agric. 46, 77-81.

Berdiales, B., Bernal, J.J., Saez, E., Woudt, B., Beitia, F., RodriguesCerezo, E., 1999. Occurrence of cucurbit yellow stunting disorder virus (CYSDV) and beet pseudo-yellows virus in cucurbit crops in Spain and transmission of CYDV by two biotypes of Bemisia tabaci. Eur. J. Plant Pathol. 105, 211-215.

Bharathan, N., Graves, N., Narayan, K.R., Schuster, D.J., Bryan, H.H., McMillan, J.R., 1990. Association of double-stranded RNA with whitefly mediated silvering in squash. Plant Pathol. 39, 530-538.

Bird, J., 1957. A whitefly transmitted mosaic of Jatropha gossypifolia. Univ. Puerto Rico, Agric. Exp. Stn., 22, 35.

Bird, J., Marmorosch, K., 1978. Viruses and virus diseases associated with whiteflies. Adv. Virus Res. 22, 55-110.

Bob, M.A., Sithanantham, S., Nono-Womdim, R., 1997. Whitefly problems in Africa: known importance and research needs. In:
Proceedings of ANPP-Fourth International Conference on Pests in Agriculture, 6-9 Jan. 1997, Montpellier, France, Vol. 3. ANPP, Paris, pp. 859-866.

Bock, K.R., 1982. Geminivirus diseases in tropical crops. Plant Dis. 66, 266-270.

Brown, J.K., 1993. Evaluacion critica sobre los biotipos de mosca blanca en America, de 1989 a 1992. In: Hilje, L., Arboleda, O. (Eds.), Las Moscas Blancas (Homoptera: Aleyrodidae) en America Central y el Caribe. Centro Agronômico Tropical de Investigación y Enseñanza. Turrialba, Costa Rica, pp. 1-9.

Brown, J.K., 1994. Current status of Bemisia tabaci as a plant pest and virus vector in agro-ecosystems worldwide. FAO Plant Prot. Bull. 42, 3-32.

Brown, J.K., 2001a. Molecular markers for the identification and global tracking of whitefly vector-begomovirus complexes. Virus Res. 71, 233-260.

Brown, J.K., 2001b. The molecular epidemiology of begomoviruses. In: Khan, J. A., Dykstra, J. (Eds.), Trends in Plant Virology. The Haworth Press, New York, in press.

Brown, J.K., Bird, J., 1992. Whitefly transmitted geminivirus in the Americas and the Caribbean Basin: past and present. Plant Dis. 76, 220-225.

Brown, J.K., Coats, S., Bedford, J.D., Markham, P.G., Bird, J., 1992. Biotypic characterization of Bemisia tabaci populations based on esterase profiles, DNA fingerprinting, virus transmission, and bioassay to key host plant species. Phytopathology 82, 1104.

Brown, J.K., Frohlich, D.R., Rossell, R.C., 1995. The sweet potato or silverleaf whiteflies: biotypes of Bemisia tabaci or a species complex? Ann. Rev. Entomol. 40, 511-534.

Burban, C., Fishpool, L.D.C., Fauquet, C., Fargette, D., Thovenel, J.C., 1992. Host-associated biotypes within west African populations of the whitefly Bemisia tabaci (Gennadius.), (Hom., Aleyrodidae). J. Appl. Entomol. 113, 416-423.

Butler Jr., G.D., Henneberry, T.J., 1986. Bemisia tabaci (Gennadius), a pest of cotton in the southwestern United States. US Dept. Agric., Agric. Res. Serv. Tech. Bull. 1701, 19.

Butler Jr., G.D., Henneberry, T.J., Hutchinson, W.D., 1986. Biology, sampling and population dynamics of Bemisia tabaci, In: Russell, G.E. (Ed.), Agric. Zool. Rev. Intercept, UK, pp. 167-195.

Byrne, D.N., Blackmer, J.L., 1996. Examination of short-range migration by Bemisia. In: Gerling, D., Mayer, R.T. (Eds.), Bemisia: 1995 Taxonomy, Biology, Damage, Control and Management. Intercept, UK, pp. 17-28.

Campbell, B.C., Stephen-Camphell, J.D., Gill, R., 1996. Origin and radiation of whiteflies: an initial molecular phylogenetic assessment. In: Gerling, D., Mayer, R.T. (Eds.), Bemisia: 1995 Taxonomy, Biology, Damage, Control and Management. Intercept, UK, pp. 29-52.

Cardona, C., 1999. Las moscas blancas (Homoptera: Aleyrodidae) como plagas de cultivos semestrales en Colombia y Ecuador: vision general del problema. In: Proceedings, Moscas blancas y thrips: un agresivo complejo de plagas agricolas de fin de mileno. Colombian Society for Entomology, Colombia, pp. 1-13.

Carver, M., Reid, I.A., 1996. Aleyrodidae (Hemiptera: Sternorrhyncha) of Australia - systematic catalogue, host plant spectra, distribution, natural enemies and biological control. CSIRO Div. Entomol. Technical Paper No. 37, 55pp.

Castle, S.J., 1999. Agricultural intensification and pest outbreaks: a reappraisal of events in the Sudan Gezira. Ann. Entomol. Soc. Amer. 92, 840-852.

Castle, S.J., Henneberry, T.J., Prabhaker, N., Toscano, N.C., 1996. Trends in relative susceptibilities of whiteflies to insecticides through the cotton season in the Imperial Valley, CA. In: Dugger, P., Richter, D. (Eds.), Proceedings Beltwide Cotton Conference. National Cotton Council, Memphis, TN, pp. 1032-1035. 
Chermiti, B., Braham, M., Cenis, J.L., Alonso, C., Beitia, F., Albajes, R., Carnero, A., 1997. On the presence in Tunisia of the biotypes "B" and "non B" of Bemisia tabaci (homoptera: aleyrodidae) and of their associated parasitoids. Bull. OILB/SROP 20, 108-113.

Coats, S.A., Brown, J.K., Hendrix, D.L., 1994. Biochemical characterisation of biotype-specific esterases in the whitefly Bemisia tabaci Genn. (Homoptera: Aleyrodidae). Insect Biochem. Mol. Biol. 24, 723-728.

Cock, M.J.N., 1986. Bemisia tabaci-A literature survey on the cotton whitefly with an annotated bibliography. FAO/CAB International Institute of Biological Control, Ascot, UK, 21pp.

Cohen, S., Harpaz, J., 1964. Periodic, rather than continual acquisition of a new tomato virus by its vector, the tobacco whitefly (Bemisia tabaci Gennadius). Entomol. Exp. Appl. 7, 155-166.

Cohen, S., Duffus, J.E., Liu, H.Y., 1992. A new Bemisia tabaci biotype in the southwestern united states and its role in silverleaf of squash and transmission of lettuce infectious yellows virus. Phytopathology $82,86-90$.

Costa, A.S., 1969. Whiteflies as virus vectors. In: Maramorosch, K. (Ed.), Viruses, Vectors and Vegetation. Wiley Interscience, New York, pp. 27-49.

Costa, A.S., 1976. Whitefly transmitted plant diseases. Ann. Rev. Phytopathol. 14, 429-449.

Costa, H.S., Brown, J.K., 1990. Variability in biological characteristic isozyme patterns and virus transmission among populations of Bemisia tabaci Genn. in Arizona. Phytopathology 80, 888.

Costa, H.S., Brown, J.K., 1991. Variation in biological characteristics and esterase patterns among populations of Bemisia tabaci, and the association of one population with silverleaf symptom induction. Entomol. Exp. Appl. 61, 211-219.

Costa, A.S., Russell, L.M., 1975. Failure of Bemisia tabaci to breed on cassava plants in Brazil (Homoptera: Aleyrodidae). Cienc. Cult. (São Paulo) 27, 388-390.

Costa, H.S., Brown, J.K., Byrne, D.N., 1991. Life history traits of the whitefly, Bemisia tabaci (Homoptera: Aleyrodidae) on six virusinfected or healthy plant species. Environ. Entomol. 20, 1102-1107.

Costa, H.S., Ullman, D.E., Johnson, M.W., Tabashnik, B.E., 1993. Squash silverleaf symptoms induced by immature, but not the adult, Bemisia tabaci. Phytopathology 83, 763-766.

Costa, H.S., Westcot, D.M., Ullman, D.E., Rosell, R., Brown, J.K., Johnson, M.W., 1995. Morphological variation in Bemisia endosymbionts. Protoplasma 189, 194-202.

Czosnek, H., Laterrot, H., 1997. A worldwide survey of tomato leaf curl viruses. Arch. Virol. 142, 1391-1406.

Dantsing, E.M., Shenderovska, L.P., 1988. Cotton whitefly. Zashch. Rast. 12, 40.

Dávila, A.G.H., 1999. La mosca blanca (Homoptera: Aleyrodidae) en Guatemala. In: VII Taller Latinoamericano y del Caribe Sobre Moscas-Blancas y Geminivirus. IPA, Recife, PE, Brazil, pp. 125-126.

De Barro, P.J., Driver, .F., 1997. Use of RAPD-PCR to distinguish the B biotype from other biotypes of Bemisia tabaci (Gennadius) (Hemiptera: Aleyrodidae). Aust. J. Entomol. 36, 149-152.

De Barro, P.J., Hart, P.J., 2000. Mating interactions between two biotypes of the whitefly, Bemisia tabaci (Hemiptera: Aleyrodidae) in Aust. Bull. Entomol. Res. 90, 103-112.

De Barro, P.J., Liebregts, W., Carver, M., 1998. Distribution and identity of biotypes of Bemisia tabaci (Gennadius) (Hemiptera: Aleyrodidae) in member countries of the secretariat of pacific community. Aust. J. Entomol. 37, 214-218.

De Barro, P.J., Driver, F., Trueman, J.W.H., Curran, J., 2000. Phylogenetic relationships of world populations of Bemisia tabaci (Gennadius) using ribosomal ITS1. Mol. Phylogenet. Evol. 16, 29-36.

Demichelis, S., Bosco, D., Manino, A., 2000. Distribution of Bemisia tabaci (Hemiptera: Aleyrodidae) biotypes in italy. Can. Entomol. $132,519-527$.
Dennehy, T.J., Williams III, L., Russell, J.S., Li, X., Wigert, M., 1996. Monitoring and management of whitefly resistance to insecticides in Arizona. In: Dugger, P., Richter, D. (Eds.), Proceedings Beltwide Cotton Conference. National Cotton Council, Memphis, TN, pp. 743-748.

Dittrich, V., Ernst, G.H., Ruesh, O., UK, S., 1990. Resistance mechanisms in sweetpotato whitefly (Homoptera: Aleyrodidae) populations from Sudan, Turkey, Guatemala, and Nicaragua. J. Econ. Entomol. 83, 1665-1670.

Duffus, J.E., 1987. Whitefly transmission of plant viruses. Curr. Topics Vector Res. 4, 73-91.

Duffus, J.E., 1996. Whitefly borne viruses. In: Gerling, D., Mayer, R.T. (Eds.), Bemisia: 1995 Taxonomy, Biology, Damage, Control and Management. Intercept, UK, pp. 255-263.

Duffus, J.E., Liu-Hsing, Y., Wisler, G.C., Li-Ru, H., 1996. Lettuce chlorosis virus - a new whitefly transmitted closterovirus. Eur. J. Plant Pathol. 102, 591-596.

Elbert, A., Overbeck, H., Iwaya, H., Tsuboi, S., 1990. Imidacloprid, a novel systemic nitromethylene analogue insecticide for crop protection. In: Proceedings of the Brighton Crop Protection Conference, Pests and Diseases. British Crop Protection Council, Farnham, UK, pp. 21-28.

Ellsworth, P.C., 1998. Whitefly management in Arizona: looking at whole systems. In: Dugger, P., Richter, D. (Eds.), Proceedings Beltwide Cotton Conferences. National Cotton Council, Memphis, TN, pp. 65-68.

Ellsworth, P.C., 1999. Whitefly management in Arizona cotton-status and needs. In: Dugger, P., Richter, D. (Eds.), Proceedings Beltwide Cotton Conferences. National Cotton Council, Memphis, TN, pp. 41-44.

Ellsworth, P.C., Jones, J.S., 2001. Cotton IPM in Arizona: a decade of research, implementation and education. In: Dugger, P., Richter, D. (Eds.), Proceedings Beltwide Cotton Conferences. National Cotton Council, Memphis, TN, pp. 1088-1096.

Ellsworth, P.C., Martinez-Carrillo, J.L., 2001. IPM of Bemisia tabaci: A case study from North America. Crop Prot. 20, 853-869.

Ellsworth, P.C., Diehl, J.W., Husman, S.H., 1996a. Establishment of integrated pest management infrastructure: a community-based action program for Bemisia management. In: Gerling, D., Mayer, R.T. (Eds.), Bemisia: 1995 Taxonomy, Biology, Damage, Control and Management. Intercept, UK, pp. 681-693.

Ellsworth, P.C., Dennehy, T.J., Nichols, R.L., 1996b. Whitefly management in Arizona cotton 1996. Univ. Arizona, Coop. Ext. Publ. No. 196004, IPM Series 3, 2pp.

Ellsworth, P.C., Diehl, J.W., Kirk, I.W., Henneberry, T.J., 1997. Bemisia growth regulators: large-scale evaluation. In: Dugger, P., Richter, D. (Eds.), Proceedings Beltwide Cotton Conference. National Cotton Council, Memphis, TN, pp. 922-929.

Ellsworth, P.C., Tronstad, R., Leser, J., Goodell, P.B., Godfrey, L.D., Henneberry, T.J., Hendrix, D., Brushwood, D., Naranjo, S.E., Castle, S., Nichols, R.L., 1999. Sticky cotton sources and solutions. Univ. Arizona, Coop. Ext. Publ. No. AZ1156, IPM Series 13, 4pp.

Eveleens, K.G., 1983. Cotton-insect control in the Sudan Gezira: analyses of a crises. Crop Prot. 2, 273-287.

Faust, R.M. (Ed.), 1992. Conference report and 5-year national research and action plan for development of management and control methodology for the sweetpotato whitefly. US Dept. Agric., Agric. Res. Serv, ARS-107, 165pp.

Flint, H.M., Naranjo, S.E., Leggett, J.E., Henneberry, T.J., 1996. Cotton water stress, arthropod dynamics, and management of Bemisia tabaci (Homoptera: Aleyrodidae). J. Econ. Entomol. 89, $1288-1300$.

Fransmann, B.A., Lea, D.R., De Barro, P.J., 1998. The distribution and parasitism of biotypes of the whitefly Bemisia tabaci in cotton areas of Queensland. In: Proceedings of the Ninth Australian Cotton Conference, pp. 461-464. 
Gawel, N.J., Bartlett, A.C., 1993. Characterisation of differences between whiteflies using RAPD-PCR. Insect Mol. Biol. 2, 33-38.

Gennadius, P., 1889. Disease of tobacco plantations in the trikonia. The aleurodid of tobacco. Ellenike Georgia 5, 1-3 (in Greek).

Gerling, D., Alomar, O., Arno, J., 2001. Biological control of Bemisia tabaci using predators and parasitoids. Crop Prot. 20, 779-799.

Giustina della, W., Martinez, M., Bertaux, F., 1989. Bemisia tabaci: le nouvel ennemi des cultures sous serres en Europe. Phytoma 406, $48-52$.

Gonzalez, R.A., Goldman, G.E., Natwick, E.T., Rosenberg, H.R., Grieshop, J.I., Sutter, S.R., Funakoshi, T., Davila-Garcia, S., 1992. Whitefly invasion in imperial valley costs growers, workers millions in losses. Calif. Agri. 46 (5), 7-8.

Goodman, R., 1981. Geminiviruses. J. Gen. Virol. 54, 9-21.

Greathead, A.H., 1986. Host plants. In: Cock, M.J.W. (Ed.), Bemisia tabaci-A Literature Survey on the Cotton Whitefly with an Annotated Bibliography. CAB International Institutes, Biological Control. Silwood Park, UK, pp. 17-26.

Guirao, P., Beitia, F., Cenis, J.L., 1997. Biotype determination of spanish populations of Bemisia tabaci (Hemiptera: Aleyrodidae). Bull. Entomol. Res. 87, 587-593.

Gunning, R.V., Byrne, F.J., Conde, B.D., Connelly, M.I., Hergstrom, K., Devonshire, A.I., 1995. First report of B-biotype Bemisia tabaci (Hemiptera: Aleyrodidae) in Australia. J. Aust. Entomol. Soc. 34, 116.

Gunning, R.V., Byrne, F.J., Devonshire, A.L., 1997. Electrophoretic analysis of non-B and B-biotype Bemisia tabaci (Gennadius) (Hemiptera: Aleyrodidae) in Australia. Aust. J. Entomol. 36, 245-249.

Harrison, B.D., 1985. Advances in geminivirus research. Ann. Rev. Phytopathol. 23, 55-82.

Harrison, B.D., Zhou, X., Otim-Nape, G.W., Liu, Y., Robinson, D.J., 1997. Role of a novel type of double infection in the geminivirusinduced epidemic of severe cassava mosaic in Uganda. Ann. Appl. Biol. 131, 437-448.

Hector, D.J., Hodkinson, I.D., 1989. Stickiness in cotton. In: ICAC Review Articles on Cotton Production Research No. 2. CAB International, Wallingford, UK, 44pp.

Heinz, K.M., 1996. Predators and parasitoids as biological control agents of Bemisia in greenhouses. In: Gerling, D., Mayer, R.T. (Eds.), Bemisia: 1995 Taxonomy, Biology, Damage, Control and Management. Intercept, UK, pp. 435-449.

Hendrix, D.L., Wei, Y., Leggett, J.E., 1992. Homopteran honeydew sugar composition is determined by both insect and plant species. Comp. Biochem. Physiol. 101B, 23-27.

Henneberry, T.J., Toscano, N.C., Faust, R.M., Coppedge, J.R. (Eds.), 1993. Sweetpotato Whitefly: 1993 Supplement to the Five-year National Research and Action Plan-First Annual Review. US Dept. Agric., Agric. Res. Serv. No. 112, 175pp.

Henneberry, T.J., Toscano, N.C., Faust, R.M., Coppedge, J.R. (Eds.), 1994. Silverleaf Whitefly (Formerly Sweetpotato Whitefly Strain B) 1994 Supplement to the 5-Year National Research and Action Plan-Second Annual Review. US Dept. Agric., Agric. Res. Serv, ARS-125, 224pp.

Henneberry, T.J., Toscano, N.C., Faust, R.M., Coppedge, J.R. (Eds.), 1995. Silverleaf Whitefly (Formerly Sweetpotato Whitefly, Strain B): 1995 Supplement to the 5-year National Research and Action Plan-Third Annual Review. US Dept. Agric., Agric. Res. Serv, 1995-2, 305pp.

Henneberry, T.J., Toscano, N.C., Faust, R.M., Coppedge, J.R. (Eds.), 1996. Silverleaf Whitefly (Formerly Sweetpotato Whitefly, Strain B): 1996 Supplement to the 5-year National Research and Action Plan-Fourth Annual Review. US Dept. Agric., Agric. Res. Serv, 1996-01, 243pp.

Henneberry, T.J., Toscano, N.C., Perring, T.M., Faust, R.M. (Eds.), 1997. Silverleaf Whitefly, 1997 Supplement to the Five-year
National Research and Action Plan: Progress Review, Technology Transfer, and New Research and Action Plan (1997-2001), Fifth Annual Review. US Dept. Agric., Agric. Res. Serv, 1997-02, 272pp.

Henneberry, T.J., Toscano, N.C., Perring, T.M., Faust, R.M. (Eds.), 1998. Silverleaf Whitefly: National Research, Action, and Technology Transfer Plan, 1997-2001 (Formerly Sweetpotato Whitefly, Strain B): First Annual Review of the Second 5-Year Plan. US Dept. Agric., Agric. Res. Serv, 1998-01, 187pp.

Henneberry, T.J., Toscano, N.C., Perring, T.M., Faust, R.M. (Eds.), 1999. Silverleaf Whitefly: National Research, Action, and Technology Transfer Plan: Second Annual Review of the Second 5-Year Plan. US Dept. Agric., Agric. Res. Serv, 1999-01, 185pp.

Henneberry, T.J., Toscano, N.C., Perring, T.M., Faust, R.M. (Eds.), 2000. Silverleaf Whitefly: National Research, Action, and Technology Transfer Plan (Formerly Sweetpotato Whitefly, Strain B): Third Annual Review of the Second 5-Year Plan. US Dept. Agric., Agric. Res. Serv, July 2000, 209pp.

Hilje, L., 1996. Introducción. In: Hilje, L. (Ed.), Metodologias para el Estudio y Manejo de Moscas Blancas y Geminivirus. CATIE, Turrialba, Costa Rica, pp. vii.

Hilje, L., Costa, H.S., Stansly, P.A., 2001. Cultural practices for managing Bemisia tabaci and associated viral disease. Crop Prot. 20, 801-812.

Hong, Y.G., Robinson, D.J., Harrison, B.D., 1993. Nucleotide sequence evidence for the occurrence of three distinct whitefly transmitted geminiviruses in cassava. J. Gen. Virol. 74, 2437-2443.

Hoyer, U., Maiss, E., Jelkman, W., Leseniann, D.E., Vetten, H.J., 1996. Identification of the coat protein gene of a sweet potato sunken vein closterovirus isolate from Kenya and evidence for a serological relationship among geographically diverse closterovirus isolates from sweet potato. Phytopathology 86, 744-750.

Husain, M.A., Trehan, K.N., 1933. Observations on the life history, bionomics and control of the whitefly of cotton (Bemisia gossypierda, n. sp.). Bull. Agric. Res. Inst., Pusa 196, 7pp.

Ioannou, N., 1985. Yellow leaf curl and other diseases of tomato in cyprus. Plant Pathol. 345, 428-434.

Johnson, M.W., Toscano, N.C., Reynolds, H.T., Sylvester, E.D., Kido, K., Natwick, E.T., 1982. Whiteflies cause problems for southern California growers. Calif. Agric. 36, 24-26.

Lacey, L.A., Fransen, J.J., Carruthers, R., 1996. Global distribution of naturally occurring fungi of Bemisia, their biologies and use as biological control agents. In: Gerling, D., Mayer, R.T. (Eds.), Bemisia: 1995 Taxonomy, Biology, Damage, Control and Management. Intercept, UK, pp. 401-433.

Lee, M.L., Ahn, S.B., Cho, W.S., 2000. Morphological characteristics of Bemisia tabaci (Gennadius) (Homoptera: Aleyrodidae) and discrimination of their biotypes in Korea by DNA markers. Korean J. Appl. Entomol. 39, 5-12.

Legg, J.P., 1999. Emergence, spread and strategies for controlling the pandemic of cassava mosaic virus disease in east and central Africa. Crop Prot. 18, 627-637.

Legg, J.P., Raya, M.D., 1998. Survey of cassava virus diseases in Tanzania. Int. J. Pest Manage. 44, 17-23.

Legg, J.P., Gibson, R.W., Otim-Nape, G.W., 1994. Genetic polymorphism amongst Ugandan populations of Bemisia tabaci (Gennadius) (Homoptera: Aleyrodidae), vector of African cassava geminivirus. Trop. Sci. 34, 73-81.

Legg, J.P., Sseruwagi, P., Kamau, J., Ajanga, S., Jeremiah, S.C., Aritua, V., Otim-Nape, G.W., Muimba-Kankolongo, A., Gibson, R.W., Thresh, J.M., 1999. The pandemic of severe cassava mosaic disease in East Africa: current status and future threats. In: Akoroda, M.O., Teri, J.M. (Eds.), Proceedings of the Scientific Workshop of the Southern African Root Crops Research Network (SARRNET), Lusaka, Zambia, 17-19 August 1998, pp. 236-251. 
Lima, L.H.C., Moretzohn, M.C., Oliveira, M.R.V., 2000. Survey of Bemisia tabaci (Gennadius) (Hemiptera: Aleyrodidae) biotypes in Brazil using RAPD markers. Genet. Mol. Biol. 23, 1-5.

Liu, H.Y., Cohen, S., Duffus, J.E., 1992. The use of isozyme patterns to distinguish sweetpotato whitefly (Bemisia tabaci) biotypes. Phytoparasitica 20, 187-194.

Livierateos, I.C., Argelis, A.D., Coutts, R.H.A., 1999. Molecular characterization of the cucurbit yellow stunting disorder virus coat protein gene. Phytopathology 89, 1050-1055.

Mahmood, T., 1999. Cotton leaf curl virus disease and its status in Pakistan. In: Proceedings of the ICAC-CCRI Regional Consultation, Insecticide Resistance Management in Cotton. Central Cotton Res. Inst., Multan, Pakistan, pp. 234-244.

Makkouk, K.M., Shebab, S., Madjalani, S.E., 1979. Tomato yellow leaf curl: incidence, yield losses, and transmission in Lebanon. Phytopathology 96, 263-267.

Mansoor, S., Khan, S.H., Hussain, M., Bashir, A., Saeed, M., Zafar, Y., Stanley, J., Briddon, R., Markham, P., Malik, K.A., 1999. DNA variants among Pakistan isolates of cotton leaf curl virus. In: Proceedings of the ICAC-CCRI Regional Consultation, Insecticide Resistance Management in Cotton. Central Cotton Res. Instit., Multan, Pakistan, pp. 261-276.

Markham, P., Bedford, J.D., Liu, S., Frolich, D.F., Rossel, R., Brown, J.K., 1996. The transmission of geminiviruses by biotypes of Bemisia tabaci (Gennadius). In: Gerling, D., Mayer, R.T. (Eds.), Bemisia: 1995 Taxonomy, Biology, Damage, Control and Management. Intercept, UK, pp. 69-76.

Martin, J.H., 1999. The whitefly fauna of Australia (Sternorrhyncha: Aleyrodidae): a taxonomic account and identification guide. Commonwealth Scientific and Industrial Research Organization, Canberra, Australia (CSIRO Entomology Technical Paper No. 38), 197pp.

Martin, J.H., Mifsud, D., Rapisarda, C., 2000. The whiteflies (Hemiptera: Aleyrodidae) of Europe and the Mediterranean basin. Bull. Entomol. Res. 90, 407-448.

Maynard, D.N., Cantliffe, D.J., 1989. Squash silverleaf and tomato irregular ripening: new vegetable disorders in Florida. Univ. Florida, Coop. Ext. Serv., Vegetable Crops Fact Sheet VC-37.

Mazyad, H.M., Omar, F., Al-Taher, K., Salha, M., 1979. Observations on the epidemiology of tomato yellow leaf curl virus disease on tomato plants. Plant Dis. Rep. 63, 695-698.

Medina Esparza, J.J., Leon Paul, R.L., 1994. Evaluation of pesticides for the control of whitefly on cotton. INIFAP-CIRNO-CEMEXI, Mexicali Valley-1993. In: Proceedings of the International Pest Work Committee, Mazatlan, Mexico. California Dept. Food Agric, Sacramento, CA, pp. 50-55.

Misra, C.S., Lamba, S.K., 1929. The cotton whitefly (Bemisia gossypiperda n. sp.). Bull. Agr. Res. Inst. Pusa. 196, 1-7.

Mohanty, A.K., Basu, A.N., 1986. Effect of host plants and seasonal factors on intraspecific variations in pupal morphology of the whitefly vector, Bemisia tabaci (Gennadius) (Homoptera: Aleyrodidae). J. Entomol. Res. 10, 19-26.

Morales, F.J. (Ed.), 2000. El Mosaic Dorado. Centro Internacional de Agricultura Tropical (CIAT), Cali, Colombia, 169pp.

Morales, F.J., 2001. Conventional breeding to Bemisia tabacitransmitted geminiviruses. Crop Prot. 20, 825-833.

Morales, F.J., Anderson, P.K., 2001. The emergence and dissemination of whitefly transmitted geminiviruses in Latin America. Arch. Virol. 146, 415-441.

Mound, L.A., 1963. Host-correlated variation in Bemisia tabaci (Gennadius) (Homoptera: Aleyrodidae). Proc. Roy. Entomol. Soc. London Ser. A 38, 171-180.

Mound, L.A., Halsey, S.H., 1978. Whitefly of the World: a Systematic Catalogue of the Aleyrodidae (Homoptera) with Host Plant and Natural Enemy Data. Wiley, New York, 340pp.
Mullins, J.W., 1993. Imidacloprid: a new nitroguanidine insecticide. In: Pest Control with Environmental Safety, American Chemical Society Symposium Series 524. American Chemical Society, Washington, DC, pp. 184-198.

Naranjo, S.E., 2001. Conservation and evaluation of natural enemies in IPM systems for Bemisia tabaci. Crop Prot. 20, 835-852.

Naranjo, S.E., Flint, H.M., 1994. Spatial distribution of preimaginal Bemisia tabaci (Homoptera: Aleyrodidae) in cotton and development of fixed-precision, sequential sampling plans. Environ. Entomol. 23, 254-266.

Naranjo, S.E., Flint, H.M., 1995. Spatial distribution of adult Bemisia tabaci (Homoptera: Aleyrodidae) in cotton and development and validation of fixed-precision sampling plans for estimating population density. Environ. Entomol. 24, 261-270.

Naranjo, S.E., Flint, H.M., Henneberry, T.J., 1995. Comparative analysis of selected sampling methods for adult Bemisia tabaci (Homoptera: Aleyrodidae) in cotton. J. Econ. Entomol. 88, 1666-1678.

Naranjo, S.E., Flint, H.M., Henneberry, T.J., 1996. Binomial sampling plans for estimating and classifying population density of adult Bemisia tabaci in cotton. Entomol. Exp. Appl. 80, 343-353.

Naranjo, S.E., Diehl, J.W., Ellsworth, P.C., 1997. Sampling whiteflies in cotton: validation and analyses of numerical and binomial models. Environ. Entomol. 26, 777-788.

Naranjo, S.E., Ellsworth, P.C, Chu, C.C., Henneberry, T.J., Riley, D.G., Watson, T.F., Nichols, R.L., 1998. Action thresholds for the management of Bemisia tabaci (Homoptera: Aleyrodidae) in cotton. J. Econ. Entomol. 91, 1415-1426.

Oetting, R.D., Buntin, G.D., 1996. Bemisia damage expression in commercial greenhouse production. In: Gerling, D., Mayer, R.T. (Eds.), Bemisia: 1995 Taxonomy, Biology, Damage, Control and Management. Intercept, UK, pp. 201-208.

Oliveira, M.R.V., Tigano, M.S., Aljanabi, S., 2000a. Molecular characterization of the whitefly, Bemisia spp. (Homoptera, Aleyrodidae) in Brazil. Pesq. Agropec. Brasil 35, 1261-1268.

Oliveira, M.A.S., Icuma, I.M., Alves, R.T., Oliveira, J.N.S., Oliveira, M.R.V., Lima, L.H.C., Lira, G.S., 2000b. Avaliação de surtos de mosca-branca em áreas do sistema produtivo de melão, soja e feijão. Embrapa Recursos Genéticos e Biotecnologia, Comunicado Técnico, No 29, 10pp.

Palumbo, J.C., Tonhasca Jr., A.J., Byrne, D.N., 1994. Sampling plans and action thresholds for whiteflies on spring melons. Univ. Arizona, Coop. Ext. Publ. No. 196004, IPM Series 1, 2pp.

Palumbo, J.C., Tonhasca, A., Byrne, D.N., 1995. Evaluation of three sampling methods for estimating adult sweetpotato whitefly. J. Econ. Entomol. 88, 1393-1400.

Palumbo, J.C., Horowitz, R., Prabhaker, N., 2001. Overview of insecticidal control and resistance management for Bemisia tabaci. Crop Prot. 20, 739-765.

Perring, T.M., 2001. The Bemisia tabaci species complex. Crop Prot. 20, 725-737.

Polston, J.E., Anderson, P.K., 1997. The emergence of whitefly transmitted geminiviruses in tomato in the western hemisphere. Plant Dis. 81, 1358-1369.

Prabhaker, N., Toscano, N.C., Henneberry, T.J., Castle, S.J., Weddle, D., 1996. Assessment of two bioassay techniques for resistance monitoring of silverleaf whitefly (Homoptera: Aleyrodidae) in California. J. Econ. Entomol. 89, 805-815.

Prabhaker, N., Toscano, N.C., Henneberry, T.J., 1998. Evaluation of insecticide rotations and mixtures as resistance management strategies for Bemisia argentifolii (Homoptera: Aleyrodiae). J. Econ. Entomol. 91, 820-826.

Price, J.F., Schuster, D.F., Short, D.T., 1986. Managing sweetpotato whitefly. Greenhouse Grower 55-57.

Quaintance, A.L., 1900. Contribution towards a monograph of the American Aleurodidae. US Dept. Agric., Tech. Ser., Bureau. Entomol. 8, 9-64. 
Quintero, C., Cardona, C., Ramirez, D., Jimenez, N., 1998. Primer registro del biotipo B de Bemisia tabaci (Homoptera: Aleyrodidae) en Colombia. Rev. Colombiana Entomol. 24, 23-28.

Riley, D.G., Palumbo, J.C., 1995. Interaction of silverleaf whitefly (Homoptera: Aleyrodidae) with cantaloupe yield. J. Econ. Entomol. 88, 1726-1732.

Robledo, C.T., Sagahón, J.C.R., 1999. Campaña contra la mosquita blanca (Homoptera: Aleyrodidae) Mexico. In: VII Taller Latinoamericano y del Caribe Sobre Moscas-Blancas y Geminivirus. IPA, Recife, PE, Brazil, pp. 165-174.

Rumei, X., 1996. The occurrence and distribution of Bemisia in China. In: Gerling, D., Mayer, R.T. (Eds.), Bemisia: 1995 Taxonomy, Biology, Damage, Control and Management. Intercept, UK, pp. 125-131.

Sauvion, N., Pavis, C., Huc, A., Roussean, M., Boissot, N., 1999. Caracterisation de Bemisia tabaci gennadius biotype B en Guadeloupe (Hemiptera: Aleyrodidae). Ann. Soc. Entomol. France 35 (Suppl.), 46-53.

Schaefers, G.A., Terry, E.R., 1976. Insect transmission of sweet potato agents in Nigeria. Phytopathology 66, 642-645.

Secker, A.E., Bedford, I.A., Markham, P.G., William, M.E.C., 1998. Squash, a reliable field indicator for the presence of B biotype of tobacco whitefly, Bemisia tabaci. In: Brighton Crop Protection Conference-Pests and Diseases. British Crop Protection Council, Farnham, UK, pp. 837-842.

Segarra-Carmona, A.E., Bird, J., Escudero, J., 1990. Silvering of Curcubita moschata (duchesne) associated with Bemisia tabaci Genn. (Homoptera: Aleyrodidae) in Puerto Rico. J. Agric. Univ. Puerto Rico 74, 477-478.

Silva Sanchez, C., 1997. Behavior of the silverleaf whitefly (Bemisia argentifolii $\mathrm{B} \& \mathrm{P})$ in the cotton crop on the coast of Hermosillo, Sonora. In: Proceedings of the International Cotton Pest Work Committee. California Dept. Food and Agric, Sacramento, CA, pp. 34.

Simmons, A.M., McCutcheon, G.S., Dufault, R.J., Hassell, R.L., Rushing, J.W., 2000. Bemisia argentifolii (Homoptera: Aleyrodidae) attacking species of medicinal herbal plants. Ann. Entomol. Soc. Am. 93, 856-861.

Singh, J., Sohi, A.S., Brar, D.S., Denholm, I., Russel, D., Briddon, R., 1999. Management of cotton leaf curl viral disease in India. In: Proceeding of the ICAC-CCRI Regional Consultation, Insecticide Resistance Management in Cotton. Central Cotton Res. Instit, Multan, Pakistan, pp. 277-278.

Strolz, H., 1992. Cotton contamination-A global view from the spinning industry. In: Proceedings of the 21st International Cotton Conference Bremen. Faserinstitut, Bremen, pp. 11-19.

Tonhasca, A., Palumbo, J.C, Byrne, D.N., 1994a. Binomial sampling plans for estimating Bemisia tabaci populations in cantaloupes. Res. Popul. Ecol. 36, 159-164.

Tonhasca, A., Palumbo, J.C, Byrne, D.N., 1994b. Distribution patterns of Bemisia tabaci (Homoptera: Aleyrodidae) in cantaloupe fields in Arizona. Environ. Entomol. 23, 949-954.

Toscano, N.C, Castle, S.J., Henneberry, T.J., Prabhaker, N., 1998. Persistent silverleaf whitefly exploits desert crop systems. Calif. Agr. 52, 29-33.

Traboulsi, R., 1994. Bemisia tabaci: a report on its pest status with particular reference to the near east. FAO Plant Prot. Bull. 42, 33-58.
Varma, D., Dhar, A.K., Mandal, B., 1992. MYMV (Mungbean Yellow Mosaic Virus) transmission and control in India. In: Green, S.K., Kim, D. (Eds.), Mungbean Yellow Mosaic Disease: Proceedings International Workshop, Bangkok, Thailand, 2-3 July 1991. Asian Vegetabale Research and Development Center, Taipei, Taiwan, pp. 8-27.

Vazquez, L.L., 1999. Mosca blanca-geminivirus en el Caribe: estado actual y perspectivas. VII Taller Latinoamericano y del Caribe Sobre Moscas-Blancas y Geminivirus. IPA, Recife, PE, Brazil, pp. 45-58.

Vetten, H.J., Hoyer, V., Maiss, E., Lessemann, D.E., Jelkmann, W., 1996. Serological detection and discrimination of geographically diverse isolates of sweet potato sunken vein closterovirus. Phytopathology 86, S100.

Viscarret, M.M., Botto, E.N., Polaszek, A., 2000. Whiteflies (Hemiptera: Aleyrodidae) of economic importance and their natural enemies (Hymenoptera: Aphelinidae, Signiphoridae) in Argentina. Rev. Chilena Entomol. 26, 5-11.

Wang, K., Tsai, J.H., 1996. Temperature effect on development and reproduction of silverleaf whitefly (Homoptera: Aleyrodidae). Ann. Entomol. Soc. Ann. 89, 375-384.

Watson, T.F., Silvertooth, J.C., Tellez, A., Lastra, L., 1992. Seasonal dynamics of sweetpotato whitefly in Arizona. Southwest. Entomol. 17, 149-167.

Winter, S., Purac, A., Legget, F., Frinson, E.A., Rossel, H.W., Hamilton, R.J., 1992. Partial characterization and molecular cloning of a closterovirus from sweet potato infected with the sweet potato virus disease complex from Nigeria. Phytopathology $82,869-875$.

Wisler, G.C., Duffus, J.E., Liu, H.Y., Li, R.H., Simone, G.W., Hochmuth, R.C., 1996. A new whitefly transmitted virus infecting tomato from Florida. Phytopathology 86, 571-572.

Wisler, G.C., Li, R.H., Liu, H.Y., Duffus, J.E., 1997. Partial molecular and cytological analyses of tomato chlorosis virus. Phytopathology 87, S104.

Wisler, G.C., Li, R.H., Liu, H.Y., Lowry, D.S., Duffus, J.E., 1998. Tomato chlorosis virus: a new whitefly transmitted phloem-limited, bipartite closterovirus of tomato. Phytopathology 88, 402-409.

Wool, D., Gerling, D., Bellotti, A.C., Morales, F.J., 1993. Esterase electrophoretic variation in Bemisia tabaci (Gennadius) (Hom. Aleyrodidae) among host plants and localities in Israel. J. Appl. Entomol. 115, 185-196.

Wool, D., Calvert, L., Constantino, L.M., Bellotti, A.C., Gerling, D., 1994. Differentiation of Bemisia tabaci (Gennadius) (Hom.; Aleyrodidae) populations in Colombia. J. Appl. Entomol. 117, 122-134.

Yassin, A.M., Nour, M.A., 1965. Tomato leaf curl disease in the Sudan and their relation to tobacco leaf curl. Ann. Appl. Biol. 56, 207-217.

Yokomi, R.K., Hoelmer, K.A., Osborne, L.S., 1990. Relationships between the sweet-potato whitefly and the squash silverleaf disorder. Phytopathology 80, 895-900.

Zhou, X., Liu, Y., Calvert, L., Munoz, C., Otim-Nape, G.W., Robinson, D.J., Harrison, B.D., 1997. Evidence that DNA-A of a geminivirus associated with severe cassava mosaic disease in Uganda has arisen by interspecific recombination. J. Gen. Virol. 78, 2101-2111. 